\title{
PENGATURAN PENCEGAHAN UANG HASIL KEJAHATAN DALAM KEGIATAN INVESTASI USAHA
}

\author{
Muhammad Fathra Fahasta \\ Universitas Riau, Indonesia, fathrafahasta@yahoo.com
}

\begin{abstract}
Evil is an act committed by a person or group of persons whose nature harms others. At this time the crimes are much developed either in the form of Corruption, Narcotics or other crimes. Along with the level of crime, the Government seeks to do the prevention and eradication with the rules of law to overcome it. Then from that writer do research about Stipulation of Money Result Of Crime In Business Investment Activity, this arise from writer observation either through mass media, development of crime rate of various forms lost the origin of crime in good way in the form of activity of Business Investment, join in Capital Market etc. Of these problems was born Law No. 15 of 2002, Law No. 25 of 2003, and Law No. 8 of 2010 on Prevention and Eradication of Money Laundering Crime.This type of research is in the form of normative juridical based on data secondary and supported by juridical historical and juridical approach of comparative. The regulation of prevention and eradication of crime of Crime in Business Investment activity has been changed will change the level of corruption, Narcotics and other crimes are still relatively high. So it can be said that prevention and eradication arrangements that are currently not effective in prevention and pemasannya, because the role of PPATK still waiting for reports from the relevant agencies.
\end{abstract}

Keywords : Prevention Settings, Barriers to a Crime.

\begin{abstract}
Abstrak
Kejahatan merupakan suatu perbuatan yang dilakukan oleh seseorang atau sekelompok orang yang sifatnya merugikan orang lain ataupun negara. Pada saat ini kejahatan-kejahatan banyak berkembang baik itu dalam bentuk Korupsi, Narkotika maupun kejahatan lainnya. Seiring dengan tingginya tingkatnya kejahatan maka Pemerintah berusaha untuk melakukan pencgahan-pecegahan maupun pemberantasan dengan menerbitkan peraturan-peraturan ataupun Undang-Undang untuk mengatasi permasalahan tersebut. Kemudian daripada itu penulis melakukan penelitian tentang Pengaturan Pencehan Uang Hasil Kejahatan Dalam Kegiatan Investasi Usaha, permasalahan ini timbul dari pengamatan penulis baik melalui media masa, perkembangan tingkat kejahatan berbagai macam bentuk yang menghilang kejahatan asal dengan bermacam cara baik itu dalam bentuk kegiatan Investasi Usaha, bergabung dalam Pasar Modal dan lain sebagainya. Dari permasalah-permasalahan tersebut lahirlah Undang-Undang Nomor 15 Tahun 2002, Undang-Undang Nomor 25 Tahun 2003, dan Undang-Undang Nomor 8 Tahun 2010 Tentang Pencegahan dan Permberantasan Tindak Pidana Pencucian Uang.

Jenis penelitian ini dalam bentuk yuridis normatif yang bertumpu pada data sekunder dan ditunjang dengan pendekatan yuridis historis dan yuridis komparatif.
\end{abstract}


Peraturan pencegahan dan pemberantasan mengenai kejahatan Tindak Pidana dalam kegiatan Investasi Usaha sudah mengalami perubahan-perubahan akan tetapi tingkat kejatan Korupsi, Narkotika dan kejahatan lainnya masih relatif tinggi. Maka dapat dikatakan pengaturan pencegahan dan pemberantasan yang ada saat ini belum efektif dalam pencegahan dan pemberantasannya, karena peranan PPATK masih bersifat menunggu laporan dari instasi-instansi yang terkait.

\section{Kata Kunci : Pengaturan Pencegahan, Hambatan Suatu Kejahatan.}

\section{Pendahuluan}

Kejahatan merupakan prilaku dan perbuatan manusia yang di lakukan pada orang lain atau pihakpihak atau lembaga-lembaga yang pada prinsipnya mengutungkan bagi yang melakukannya, sedangkan kejahatan itu berkembang seiring dengan kemajuan peradaban manusia. Pada dekade saat ini dengan kemajuan teknologi dan globalisasi keuangan menyebabkan transaksi dalam negeri dan antarnegara dimungkinkan berlangsung hanya beberapa detik. ${ }^{1}$

$$
\text { Secara formal, upaya }
$$
pencegahan dan pemberantasan pencucian uang di Indonesia dimulai pada tanggal 17 April 2002 yaitu saat diberlakukannya Undang-Undang Nomor 15 Tahun 2002 tentang Tindak Pidana Pencucian Uang. Sesungguhnya, tahapan pencegahan pencucian uang sudah dilakukan sebelum undang-undang tersebut lahir namun lingkupnya hanya terbatas pada Bank. Hal ini dapat ditunjukkan melalui seperangkat regulasi yang dikeluarkan oleh otoritas perbankan yang lebih dikenal dengan Peraturan Bank Indonesia tentang Prinsip Mengenal Nasabah.

${ }^{1}$ Weingast, B.R, The economic role of political institutions : market-preserving federalism and economic development, Journal of Law, Economics, and Organization 11 (1), 1995, hlm.1-31.
Urgensi pengaturan ini, tentu didasari oleh alasan yang kuat terutama mengenai dampak yang ditimbulkan oleh kegiatan pencucian uang dalam perekonomian dan untuk memenuhi prinsip-prinsip pengawasan Bank secara efektif sesuai standar Internasional.

Sebagaimana telah disinggung dimuka bahwa aktifitas pencucian uang secara umum merupakan suatu cara menyembunyikan atau menyamarkan asal usul harta kekayaan yang diperoleh dari hasil tindak pidana sehingga nampak seolah-olah harta kekayaan dari hasil tindak pidana tersebut sebagai hasil kegiatan yang sah. Lebih rinci di dalam Pasal 1 angka 1 UndangUndang Nomor 15 tahun 2002 tentang Tindak Pidana Pencucian Uang sebagaimana telah diubah dengan Undang-Undang Nomor 25 Tahun 2003 (UU TPPU), pencucian uang didefinisikan sebagai perbuatan menempatkan, mentransfer, membayarkan, membelanjakan, menghibahkan, menyumbangkan, menitipkan, membawa ke luar negeri, menukarkan, atau perbuatan lainnya atas Harta Kekayaan yang diketahui atau patut diduga merupakan hasil tindak pidana dengan maksud untuk menyembunyikan atau menyamarkan asal usul Harta Kekayaan sehingga seolah-olah menjadi harta kekayaan yang sah. 
Kemudian dari pada itu untuk mengatasi terjadinya seseorang melakukan tindakan kejahatan pencucian uang maka Pemerintah menerbitkan suatu peraturan tentang pengaturan pencegahan tindak pidana pencucian uang yakni Undang-Undang Nomor 8 Tahun 2010, dan Undang-Undang ini membetuk suatu lembaga yang bersifat independen yang di tegaskan dalam Pasa 1 ayat 2 yang berbunyi sebagai berikut :

Pusat Pelaporan dan Analisis

Transaksi Keuangan yang selanjutnya disingkat PPATK adalah lembaga independen yang dibentuk dalam rangka mencegah dan memberantas tindak pidana Pencucian Uang.

Satjipto Rahardjo mengatakan bahwa pencegahan dan pemberantasan Money Laundering tidak cukup dilakukan dengan cara konvensional, harus dilakukan dengan cara yang berbeda dan di luar kelaziman penanggulangan kejahatan lainnya. $^{2}$ Salah satu upaya yang dapat dilakukan tersebut adalah mendorong agar hukum mampu berperan dalam upaya menciptakan kontrol guna mencegah hasil tindak pidana pencucian uang untuk dinikmati oleh para penjahat, di samping itu upaya ini merupakan bentuk dari asset recovery (pengamanan aset).

\begin{tabular}{lrr}
\multicolumn{2}{c}{ Kemudian } & Andrew \\
Haynes mengatakan & bahwa \\
paradigma baru dalam \\
pencegahan kejahatan & dapat \\
dilakukan dengan rara & caran \\
menghilangkan nafsu dan \\
motivasi pelaku kejahatan untuk
\end{tabular}

2 Satjipto Rahardjo, Membedah Hukum Progresif, Kompas, Jakarta, 2006, hlm. 127. melakukan kejahatan, dengan cara menghalanginya untuk menikmati hasil atau buah dari kejahatan yang dilakukannya. ${ }^{3}$

Dalam kegiatan usaha maupun kegiatan investasi di atur dalam Undang-Undang Nomor 40 Tahun 2007 Tentang Perseroan Terbatas sedangkan dalam penanaman modal maupun dalam bentuk saham diatur dalam pasal 31 yakni :

(1) Modal dasar Perseroan terdiri atas seluruh nilai nominal saham.

(2) Ketentuan sebagaimana dimaksud pada ayat (1) tidak menutup kemungkinan peraturan perundang-undangan di bidang pasar modal mengatur modal Perseroan terdiri atas saham tanpa nilai nominal. Sedangkan nilai nominal maupun besarnya penanaman modal dalam Perseroan Terbatas tersebut diatur dalam pasal 32

(1) Modal dasar Perseroan paling sedikit Rp50.000.000,00 (lima puluh juta rupiah).

(2) Undang-undang yang mengatur kegiatan usaha tertentu dapat menentukan jumlah minimum modal Perseroan yang lebih besar daripada ketentuan modal dasar sebagaimana dimaksud pada ayat (1).

(3) Perubahan besarnya modal dasar sebagaimana dimaksud pada ayat (1), ditetapkan dengan peraturan pemerintah. ${ }^{4}$

${ }^{3}$ Dikutip dari paper yang ditulis untuk mendukung Delegasi RI Pada ForthySeventh Session of The Comision on Narcotic Drugs, diselenggarakan di Wina 15-22 Maret 2004, hlm. 2.

${ }^{4}$ Undang-Undang Nomor 40 Tahun 2007 Tentang Perseroan Terbatas. 
Dalam penelitian ini penulis mengadakan penelitian tentang pengaturan pencegahan tindak kejahatan pidana yang berusaha mengaburkan hasil tindak kejahatannya dalam bentuk investasi usaha maka dengan permasalahmaslahn tersebut yang telah duraikan di atas untuk itu penulis memberikan judul dengan dalam penelitian ini "Pengaturan Pencegahan Uang Hasil Kejahatan Dalam Kegiatan Investasi Usaha”.

\section{Rumusan Masalah}

Bertolak dari latar belakang tersebut di atas tentang pengaturan pencegahan uang hasil kejahatan dalam kegiatan investasi usaha maka dalam penelitian ini penulis menarik dan merumuskan suatu masalah sebagai berikut :

Bagaiamanakah pengaturan pencegahan tindak pidana Pencucian Uang dalam kegiatan investasi usaha?

\section{Tujuan Penelitian}

Bertolak dari rumusan masalah dalam suatu penelitian maka tujuan penelitian sebagai berikut :

Untuk mengetahui pengaturan pencegahan tindak pidana Pencucian Uang dalam kegiatan investasi usaha.

\section{Kegunaan Penelitian}

Berdasarkan

permasalahan yang menjadi fokus kajian penelitian ini dan tujuan yang ingin dicapai maka, diharapkan penelitian ini dapat memberikan manfaat sebagai berikut :

1. Manfaat Praktis

Penelitian ini diharapkan mampu memberikan sumbangan pemikiran atau bahan pertimbangan bagi legislatif dalam merumuskan hukum pidana terhadap pelaku pelaku Tindak Pidana dalam kegiatan Investasi Usaha.

\section{Manfaat Teoritis}

Memberikan sumbangan pemikiran berupa konsep, metode atau teori dalam studi ilmu hukum, khususnya yang menyangkut tindak pidana dalam kegiatan Investasi Usaha bagi penegak Hukum maupun kebijaksanaan Legislatif dalam merumuskan Hukum Pidana yang berkaitan dengan Money Laundering pada masa yang akan datang.

\section{Metode Penelitian}

Menurut Sunaryati Hartono, metode penelitian adalah cara atau jalan atau proses pemeriksaan atau penyelidikan yang menggunakan cara penalaran dan berfikir yang logis-analitis (logika), berdasarkan dalil-dalil, rumus-rumus dan teoriteori suatu ilmu (atau beberapa cabang ilmu) tertentu, untuk menguji kebenaran (atau mengadakan verifikasi) suatu hipotesis atau teori tentang gejala-gejala atau peristiwa alamiah, peristiwa sosial atau peristiwa hukum yang tertentu. ${ }^{5}$

\section{Pembahasan}

Pengaturan Pencegahan Tindak Pidana Pencucian Uang Dalam Kegiatan Investasi Usaha.

\section{A. Komisi Pemberantasan Korupsi (KPK)}

Bahwa kewenangan melakukan penyelidikan terhadap atau untuk Tindak Pidana Korupsi,bagi penyidik KPK didasarkan pada pasal 6

5 Sunaryati Hartono, Penelitian Hukum di Indonesia Pada Akhir Abad ke20 , Alumni, Bandung, 1994. hlm. 105. 
Undang-Undang Nomor 30 tahun 2002 tenyang Komisi Pemberantasan Korupsi. Selanjutnya dasar hukum untuk melaksanakan Penyidikan untuk Tindak Pidana Pencucian Uang yang berasal dari tindak pidana korupsi yang penyidikannya ditangani oleh Penyidik KPK merujuk pada Undang-undang Nomor 30 tahun 2002 tentang Komisi Pemberantasan Korupsi, Undang-Undang Nomor 20 Tahun 2001 tentang perubahan atas Undang-Undang Nomor 31 tahun 1999 Tentang Pemberantsan Tindak Pidana Korupsi dan selebihnya mengacu pada KUHAP.

Penyidikan,penuntutan, dan pemeriksaan di sidang pengadilan serta pelaksanaan putusan yang telah mempperoleh kekuatan hukum tetap terhadap Tindak Pidana sebagaimana dimadsud dalam Undang-Undang ini dilakukan sesuai dengan ketentuan peraturan perundang-undangan.

Disamping itu dalam usaha pencegahan tindak pidana dalan kegiatan investasi usaha dapat dilakukan melalui Pendekatan sumber daya baik sumber daya manusia maupun sumber daya keuangan menunjukkan bahwa kelemahan yang mendasar dalam sektor ini sangat menentukan kinerja pelaksanaan strategi pemberantasan korupsi. Sumber daya manusia terutama yang melakukan penegakan hukum terhadap tindak pidana korupsi harus didukung oleh sarana dan prasarana yang memadai dengan anggaran yang cukup. Mereka harus memiliki kemampuan, kejujuran, integritas serta tanggung jawab, dan sudah tentu dengan tidak melupakan faktor kesejahteraan. Strategi Nasional Pemberantasan Korupsi ini memerlukan dukungan yang luas dan kuat dari seluruh masyarakat, termasuk dukungan terhadap Lembaga Swadaya Masyarakat (LSM) yang komit dengan usaha pemberantasan korupsi seperti Indonesia Corruption Watch (ICW), Masyarakat Anti Korupsi (MAK).

Upaya pencegahan korupsi yang berhubungan dengan money laundering di Indonesia harus dimulai dengan pemahaman terhadap eksistensi korupsi itu sendiri. Kondisi faktual yang ada sampai sekarang menunjukkan bahwa dalam upaya penegakan hukum terhadap korupsi, masih ada perbedaan pemahaman antara masyarakat, pemerintah dan dunia usaha tentang eksistensi korupsi. Perbedaan ini adalah konsekuensi dari adanya perbedaan cara pandang, kepentingan dan pengetahuan. Oleh sebab itu, sosialisasi tentang eksistensi korupsi kepada semua lapisan masyarakat sangat penting untuk membangun kesamaan visi dan misi dalam memandang korupsi sebagai musuh bersama (common enemy).

B. Pusat Pelaporan Analisis Transaksi Keuangan (PPATK) Pusat Pelaporan Analisis Transaksi Keuangan dalam melaksanakan tugasnya di atur dalam Undang-Undang Nomor 8 Tahun 2010 Tentang Pencegahan dan pemberantasan Tindak Pidana Pencucian Uang dan Peraturan Presiden Nomor 50 Tahun 2011. Sedangkan tugas pokok PPATK adalah memberantas dan mencegah tindak pidana pencucian uang.

Keterbatasan regulasi yang terkait dengan pengaturan kelembagaan, dirasakan membuat lembaga ini tidak dapat memaksimalkan peran dan fungsinya.Sementara itu maraknya kasus-kasus pencucian uang yang terjadi akhir-akhir ini sangat 
meresahkan masyarakat. Kelemahan dalam perundang-undangan inilah yang dimanfaatkan pelaku untuk tidak takut melakukan tindak pidana pencucian uang. Bahkan pelaku dengan sengaja membawa lari hasil kejahatan ke luar negeri supaya tidak dapat tersentuh aparat penegak hukum. Kenyataan nilah yang kemudian membuat pemerintah untuk sesegera mungkin memperbaiki ketentuan yang ada. Sementara ketentuan baru yang membutuhkan ketentuan pendukung, juga belum sesegera mungkin direalisir.Sehingga yang terjadi undang-undang yang baru seakanakan tidak mampu menghadapi persoalan yang semakin kompleks. Kerjasama yang menjadi sebuah solusi dalam pencegahan dan pemberantasan tindak pidana pencucian uang, memang banyak mengalami kendala teknis dalam pelaksanaannya. Sehingga kerjasama yang selama ini terjadi hanya bersifat formalitas dan belum menunjukkan ke arah meningkatnya penanganannya tindak pidana pencucian uang. Hal ini dapat dilihat dari keberhasilan pengembalian asset ke tanah air yang selama ini diusahakan oleh pemerintah melalui jalur kerjasama dengan luar negeri. Banyak aset-aset yang ditempatkan di luar negeri yang tidak mampu di bawa kembali ke tanah air dengan alasan karena perbedaan sistem hukum, dan ketidak mampuan diplomasi pemerintah Indonesia dengan pemerintah negara dimana aset di tempatkan.

Disamping itu kejahatan yang di lakukan oleh koruptor untuk menghilangkan jejaknya yang lazim di sebut money laundering yang empuk dalam bidang usaha yakni pada Pasar Modal, dan Proses
Pencucian Uang dari Hasil Kejahatan Tindak Pidana Korupsi dapat di lakukan bermacam cara, untuk megetahui cara-cara tersebut dapat dilihat dari uraian sebagai berikut :

1. Modus Pencucian Uang Di Pasar Modal

Segenap tindak pidana di pasar modal berkaitan dengan pencucian uang. Pengertian tindak pidana pencucian uang di pasar modal mengandung makna bahwa, pencucian uang dapat dilakukan atas harta kekayaan yang berasal dari hasil tindak pidana, berdasarkan ketentuan Pasal 2 Undang-Undang TPPU. Selain itu, tindak pidana asal dapat pula berupa tindak pidana lainnya di luar tindak pidana pasar modal, sehingga dengan demikian, diperoleh pemahaman bahwa pencucian uang di pasar modal dapat bermakna, Pencucian uang di pasar modal atas hasil tindak Pidana pasar modal; atau Pencucian uang di pasar modal atas tindak pidana lainnya seperti korupsi, pembalakan liar, penipuan, bisnis narkoba, dan lainlain.

2. Ada beberapa poin yg perlu digaris bawahi kenapa seseorang itu melakukan tindak pidana pencucian uang dalam pasar modal :

a. Perdagangan di pasar saham/modal itu sifatnya internasional, itu mendasari seseorang bisa membeli saham di mana pun (artinya seseorang bisa melakukan, membeli saham di mana saja). Ada kemungkinan jika koruptor yang dari Indonesia bisa membeli saham di negara yang sistem keuangannya lemah dan sebaliknya.

b. Instrument yang diperdagangkan dalam pasar modal antara lain 
seperti saham, reksa dana, yangg sifatnya liquid (mudah diuangkan,dicairkan, dibeli atau mudah dijual).

c. Kompetisi pelaku dalam pasar modal itu sangat kompetitif, maksudnya pelaku industri dalam pasar modal seperti bursa efek, majemen infestasi (broker), dan infestor yang punya banyak uang, dikatakan sangat kompetitif contonya ketika ada seorang agen sebagai perusahaan efek ingin membeli efek itu sendiri tanpa memperhatikan keabsahan/legalitas uang dari investor, yang terpenting ialah keuntungan dari membeli saham lebih diutamakan sebelum dibeli oleh infestor lain, itulah yang mendorong orang untuk melakukan tindak pidana pencucian uang tanpa ada yang memperhatikan dari mana asalusul uang tersebut.

d. Dalam pembelian produkproduk dalam pasar modal antara lain seperti saham, itu biasanya menggunakan nama orang lain, memakai nama orang lain, atau menyuruh orang lain menggunakan namanya tanpa mesti bertanya-tanya asal usul uangnya.

3. Proses Pencucian Uang dari Hasil Kejahatan Tindak Pidana Korupsi

Proses pencucian uang dari hasil tindak pidana korupsi pada hakikatnya adalah sama dengan proses pencucian uang dari hasil kejahatan-kejahatan lain yang tergolong sebagai predicate crime sebagaimana dimuat dalam pasal 2 ayat 1 UndangUndang Nomor 8 Tahun 2010 tentang Pencegahan dan Pemberantasan Pencucian Uang, hasil tindak pidana korupsi tidak memiliki perbedaan yang khusus dengan proses pencucian uang dari hasil kejahatan lainnya seperti halnya narkotika maupun terorisme. Seseorang atau organisasi kejahatan melakukan pencucian uang sebagaimana telah dikemukakan sebelumnya tujuannya adalah agar asal-usul uang tersebut tidak dapat diketahui atau tidak dapat dilacak oleh penegak hukum.

\section{Kepolisian}

Di dalam Kitab UndangUndang Hukum Acara Pidana (KUHAP), salah satu institusi yang diberi kewenangan untuk melakukan penyelidikan dan penyidikan adalah Kepolisian Negara Republik Indonesia. Selain dalam KUHAP, kewenangan polisi sebagai penyelidik dan penyidik untuk mengungkap tindak pidana, ditegaskan kembali dalam Pasal 1 angka 8 dan 9, dan Pasal 14 ayat (1) huruf $g$ UndangUndang No. 2 Tahun 2002 tentang Kepolisian Negara Republik Indonesia yang menyatakan: melakukan penyelidikan dan penyidikan terhadap semua tindak pidana sesuai dengan hukum acara pidana dan peraturan perundangundangan lainnya.

Untuk mencari jalan keluar dalam rangka mencegah dan menanggulangi tindak pidana pencucian uang oleh Kepolisian terdapat upaya-upaya yang dapat dilakukan antara lain:

a.Upaya Pre-entif

b. Upaya Preventif

c. Upaya Represif

Upaya Pre-Entif disini adalah upaya-upaya awal yang 
dilakukan untuk mencegah terjadinya tindak pidana. Usahausaha yang dilakukan dalam penanggulangan kejahatan secara pre-entif adalah menanamkan nilai-nilai/normanorma yang baik sehingga norma-norma tersebut terinternalisasi dalam diri seseorang. Meskipun ada kesempatan untuk melakukan pelanggaran atau kejahatan tapi tidak ada niatnya untuk melakukan hal tersebut maka tidak akan terjadi kejahatan. Jadi dalam usaha pre-entif faktor niat menjadi hilang meskipun ada kesempatan. ${ }^{6}$

Upaya-upaya preventif ini adalah merupakan tindak lanjut dari upaya Pre-Entif yang masih dalam tataran pencegahan sebelum terjadinya kejahatan. Dalam upaya preventif yang ditekankan adalah menghilangkan kesempatan untuk dilakukannya kejahatan. ${ }^{7}$ Tindakan Represif ialah segala tindakan yang dilakukan oleh aparatur penegak hukum sesudah terjadi kejahatan atau tindak pidana. Telah dikemukakan di atas, bahwa tindakan represif sebenarnya juga dapat dipandang sebagai preventif dalam arti luas. Termasuk tindakan represif adalah penyidikan, penyidikan lanjutan, penuntutan dan seterusnya sampai dilaksanakannya. $^{8}$

6

http://digilib.unila.ac.id/6264/13/BAB\%20I. pdf diakses pada 26 Oktober 2017

${ }_{8}^{7}$ Ibid.

http://www.medanbisnisdaily.com/news/rea d/2014/12/16/135728/bi- gandeng-poldasu-

\section{Penutup \\ Kesimpulan}

a. Dengan tingginya tingkat kejahatan baik dalam bentuk Korupsi, Narkotika dan lain sebagainya yang dilakukan secara individu maupun kelompok, sedangkan hasil kejahatan tersebut dikaburkan dari yang tidak sah menjadi sah, baik dalam bentuk kegiatan Investasi Usaha maupun dalam bentuk penyimpanan melalui Perbankan, sedangkan prilaku tersebut lazim di kenal dengan Tindak Pidana Money Laundering. Untuk itu Pemerintah berusaha mencegah dan memberantasnya maka secara formal upaya pencegahan dan pemberantasan pencucian uang di mulai pada tanggal 17 April dengan terbitnya UndangUndang Nomor 15 Tahun 2002 Tentang Tindak Pidana Pencucian Uang, diadakan perubahan dengan UndangUndang Nomor 25 Tahun 2003, dan untuk penyempurnaan pencegahan dan pemberantasan Money Laundering maka diadakan perubahan lagi dengan terbitnya Undang-Undang Nomor 8 Tahun 2010 Tentang Pencegahan dan Pemberantasan Tindak Pidana Pencucian Uang.

b. Peranan Pusat Pelaporan Analis Transaksi Kuangan (PPATK) dalam pencegahan dan pemberantasan Tindak Pidana Pencucian Uang sangat berperanan, namun dalam pelaksanaanya sering mengalami permasalahan, dalam hal ini

awasi-transaksi-valas-di-sumut/diakses pada 26 Oktober 2017 
dapat dibuktikan dengan masih tingginya tingkat kejahatan Korupsi, Narkotika dan lainnya. Hal ini disebabkan PPATK dalam melaksanakan tugasnya hanya menerima hasil laporan dari pihak Pemberi Jasa Keuangan, Perbankan, dan Bea dan Cukai maka sistim ini sangat sulit untuk melakukan pencegahan dan pemberansan kejahatan tersebut.

\section{Saran}

a. Perlu di adakan perubahan pada Pasal-Pasal tertentu dengan memasukkan Pusat Pelaporan Analis Transaksi Keuangan (PPATK) untuk berdiri sendiri melalukan pencegahan dan pemberantasan hasil-hasil kejahatan dari unsur pengimpunan data keuangan yang telah dilakukan oleh pelaku kejahatan dengan berkerjasama pada unsur-unsur tertentu untuk di Analisa dan diberikan kepada Penegak Hukum. Dalam hal ini PPATK tidak menerima laporan dari pemberi Jasa Keuangan, Perbankan, dan Bea dan Cukai.

b. Dalam Pembuatan Kartu Tanda Penduduk (KTP), Dinas Kependudukan dan Catatan Sipil mencatat Indentitas Keluarga, maupun harta kekayaan yang di milikinya maupun keluarganya, sehingga data kekayaan Penduduk Indonesia bisa di ketahui secara dini dan dapat di akses oleh siapa pun.

\section{Daftar Pustaka}

\section{Buku}

Amirudin \& Zainal Asikin, 2004, Pengantar Metode Penelitian Hukum,
RadjaGrafindo Persada, Jakarta.

Ahmad Muhammad AI 'AssaI dan Fathi Ahmad Abdul Karim, 1999, Sistem, Prinsip dan Tujuan Ekonomi Islam, Pustaka Setia. Bandung.

Barda Nawawi Arief, 2000, Kebijakan Legislatif dalam Penanggulangan Kejahatan dengan Pidana Penjara, Badan Penerbit Undip, Semarang.

2008,

Masalah Penegakan Hukum Pidana dalam Penanggulangan Kejahatan, Kencana Prenada Media Group, Jakarta.

,2008, Bunga

Rampai Kebijakan Hukum

Pidana, Perkembangan Penyusunan Konsep KUHP Baru, Kencana, Jakarta.

2008 , Perbandingan Hukum Pidana, RadjaGrafindo Persada, Jakarta.

Evi Hartanti, 2005, Tindak Pidana Korupsi, Sinar Grafika, Jakarta.

GufTon A. Mas'di, 2002, Fiqh

Aluamlah Kontekslual, Radja Grafindo Persada bekerjasama dengan IArN Walisongo Semarang,2002. 
Jhon Dombrink, dalam Thomas Barker \& David L. 1999 Carter, Police Deviance (Penyimpangan Polisi), Cipta Manunggal, Jakarta.

M. Solly Lubis, 1985, Pembahasan UUD 45, Alumni, Bandung.

Muladi dan Barda Nawawi Arief, 1992, Bunga Rampai Hukum Pidana, Alumni, Bandung.

Miftah Fariedl, 2000, Konsep dan Etika Bisnis Perbankan Syariah. Makalah pada Seminar Nasional Perbankan Syariah, LPPM UNPAD dan BI, Bandung.

Nyoman Serikat Putra Jaya, 2005,

Tindak Pidana Korupsi, Kolusi dan Nepotisme di Indonesia, Badan Penerbit Undip, Semarang. , 2008,

Beberapa Pemikiran ke

Arah Pengembangan

Hukum Pidana, Citra Aditya

Bakti, Bandung.

Romli Atmasasmita, 2004, Sekitar

Masalah Korupsi,Aspek

Nasional dan Aspek

Internasional, Mandar

Maju, Bandung.

Robert Klitgaard (diterjemahkan oleh Yayasan Obor), 1998, Membasmi Korupsi, Yayasan Obor Indonesia, Jakarta. (alih bahasa

oleh Masri Maris), 2005,

Penuntun Pemberantasan

Korupsi Dalam

Pemerintahan Daerah,

Yayasan Obor Indonesia, Jakarta.

Ronny Hanitijo Soemitro, 1982, Metodologi Penelitian Hukum, Ghalia Indonesia, Jakarta

Soerjono Soekanto, 2002, Faktorfaktor yang Mempengaruhi Penegakan Hukum, RadjaGrafindo Persada, Jakarta.

Soerjono Soekanto \& Sri Mamudji, 1983, Penelitian Hukum Normatif Suatu Tinjauan Singkat, RadjaGrafindo Persada, Jakarta.

Satjipto Rahardjo, 2009, Penegakan Hukum, Suatu Tinjauan Sosiologis, Genta Publishing, Yogyakarta.

Sunaryati Hartono, 1994, Penelitian Hukum di Indonesia Pada Akhir Abad ke-20, Alumni, Bandung.

Sunariyah, 2004, Pengantar Pengetahuan Pasar Modal, Edisi ke Empat, UPP-AMP YKPN, Yogyakarta.

2. Peraturan PerundangUndangan 
Undang-Undang Nomor 8 Tahun 2010 Tentang Pencegahan dan pemberantasan Tindak Pidana Pencucian Uang. Tambahan Lembaran Negara Republik Indonesia Nomor 5164

Undang-Undang Nomor 40 Tahun 2007 Tentang Perseroan Terbatas. Tambahan Lembaran Negara Republik Indonesia Nomor 4756.

Undang-Undang Nomor 25 Tahun 2003 Tentang Tindak Pidana Pencucian Uang. Tambahan Lembaran Negara Republik indonesia Nomor 108

\section{Jurnal}

Adam Graycar, Aiden Sidebottom, 2012, Corruption and control: a corruption reduction approach, Journal of Financial Crime, Vol. 19 Issue: 4, Pages 384-399.

Becker, G.S., Stigler, G.J., 1974. Law enforcement, malfeasance, and the compensation of enforcers. Journal of Legal Studies 3 (1), Pages 1-18.

La Porta, R., Lopez-de-Silanes, F., Shleifer, A., Vishny, R.W., 1999, The quality of government, Journal of Law, Economics and Organization 15 (1), Pages 222-279.

Taswan dan Soliha,2002, Pengaruh Kebijakan Hutang Terhadap Nilai Perusahaan Serta Beberapa Faktor yang Mempengaruhinya. Junrnal Ekonomi dan Bisnis, STIE Stikubank, Semarang.

Weingast, B.R., 1995, The economic role of political institutions : market-preserving federalism and economic development. Journal of Law, Economics, and Organization 11 (1), Pages 1-31. 